\title{
More Equal Than Others? A Comparative Analysis of State and Non-state Perceptions of Interest Representation and Decision-making in REDD+ Negotiations
}

\author{
Tim Cadman $^{\mathrm{a}^{*}}$ and Tek Maraseni ${ }^{\mathrm{b}}$ \\ ${ }^{a}$ Key Centre for Law, Ethics, Justice and Governance, Griffith University, Nathan, \\ Queensland, Australia; ${ }^{b}$ Australian Centre for Sustainable Catchments, University of \\ Southern Queensland, Towoomba, Australia
}

\begin{abstract}
This paper provides a quantitative analysis of stakeholder perceptions regarding the governance of the UN climate change negotiations on reducing emissions from deforestation and forest degradation in developing countries (REDD+). Governance quality and legitimacy was evaluated by means of an online survey conducted in 2011, using a normative framework of principles, criteria and indicators. The paper concentrates on national-level stakeholders active in REDD+ in Nepal, and their perceptions of governance quality, with a discussion, given the focus of this special volume, that emphasises inclusiveness, equality and resources (indicators of interest representation) and democracy, agreement and dispute settlement (indicators of decision-making). Respondents were selected from state (i.e. governmental) and nonstate (i.e. civil society) interests from a range of sectors active in REDD+ at the national level. The results show that survey respondents generally found REDD+ to be inclusive, but did not consider that there was the necessary capacity, or resources, for meaningful participation. A concluding section reviews the framework applied, and comments on the nature of multi-stakeholder relations in contemporary global governance, and REDD+ specifically.
\end{abstract}

Keywords: Global environmental governance; interest representation; decisionmaking; quality; legitimacy; REDD+

\section{Introduction: climate change, state and non-state actors, and the role of the market}

Climate change management constitutes one of the most significant regimes to emerge from the 1992 Rio 'Earth' Summit. The United Nations Framework Convention on Climate Change (UNFCCC) has its own sets of institutional arrangements, replete with a variety of governance systems, to solve the problem of climate change through market-based or other sustainable development initiatives, including the Kyoto Protocol and emerging replacements. Although multilateral environmental agreements remain the central framework in which environmental negotiations take place, implementation occurs through a range of mechanisms, both public and private, which function on many different levels and include many different actors - not just governments (Andonova et al. 2009). Within the climate change management arena, there is an increasing inclination to opt for social-political methods of stakeholder interaction. The United Nations Collaborative Programme for

\footnotetext{
*Corresponding author. Email: tim.cadman@usq.edu.au
} 
Reducing Emissions from Deforestation and Forest Degradation in Developing Countries (now referred to as REDD+) epitomises this trend.

Institutional arrangements include decentralised networks with a variety of interested parties cooperating at multiple levels of organisation, including non-state interests such as civil society organisations (CSOs) (Juhola and Westerhoff 2011). This challenges previous conceptions of state-based legitimacy (Bulkeley 2010). The increasing reliance on marketbased governance systems has further encouraged collaboration between state and non-state actors, even if nation states have the final say (Andonova et al. 2009). Various initiatives that use trade as a basis for sustainable development have given rise to the term 'non-state marketdriven (NSMD) governance' (Cashore et al. 2004). Such initiatives cover a wide range of commodity sectors, from fisheries through to forestry and agriculture (Gulbrandsen 2005). Carbon has now become such a commodity in a range of trade-based mechanisms, including the Clean Develop Mechanism (CDM), and the emergent REDD+, which is currently a subject of discussion at climate negotiations.

In the wake of Rio and the globalisation of environmental policy, it is important to understand the conceptual evolution in thinking about governance; in particular, the emphasis on deliberative approaches to decision-making and how these new approaches are reflected in the climate policy arena. The conceptual framework of this study is consequently informed by what can be termed 'new governance' literature: that is, new processes of governing within systems of public and private administration (Rhodes 1997). The centrality of participation and deliberation to what is referred to as 'social-political interaction' (Kooiman 2000) forms the basis of the institutional analysis below. The analysis focuses on both state (governmental) and non-state (civil society) stakeholders within the merging international REDD+ negotiations within UNFCCC as they evolved over the period 2009-2011. Taking the case of Nepal, the paper begins by presenting an integrated method for the evaluation of governance, and continues with a focussed discussion on interest representation and decisionmaking. It continues with a brief outline of REDD+ itself, before presenting the results of a series of Internet surveys of state and non-state stakeholder perceptions of governance quality. It finds that perceptions vary between the state and non-state actors, but that there are a number of trends across the groups, demonstrating shows what is both 'good' and 'bad' with REDD+ as an example of global environmental governance.

\section{The legitimacy of market-driven governance: developments in theory and research}

Contemporary governance is increasingly understood in terms of both structure and process (Pierre and Peters 2000). This study evaluates quality of climate governance by examining the participatory structures, deliberative processes, substantive products and longer-term outcomes of a given institution, because it is these factors that ultimately determine the effectiveness of that institution. Rather than evaluating the performance of an institution on the basis of a few individual attributes (e.g. inclusiveness, equality or decision-making), the governance system can be viewed as a whole, with legitimacy as the end point of activity within the institution (Author 1 2011). Legitimacy is determined by the degree of successful interaction between the structural and procedural components (inputs) of the institution's governance system; that is, the rules, standards and so on. This interaction creates outputs, and the longer-term behavioural and problem-solving impacts these generate on the ground (outcomes). In combination, the quality of inputs, outputs and outcomes determine legitimacy (Figure 1). It is necessary 
to conceive of legitimacy in such terms, because legitimacy has been seen as an emerging analytical problem among governance scholars (Biermann et al. 2009; 2011).

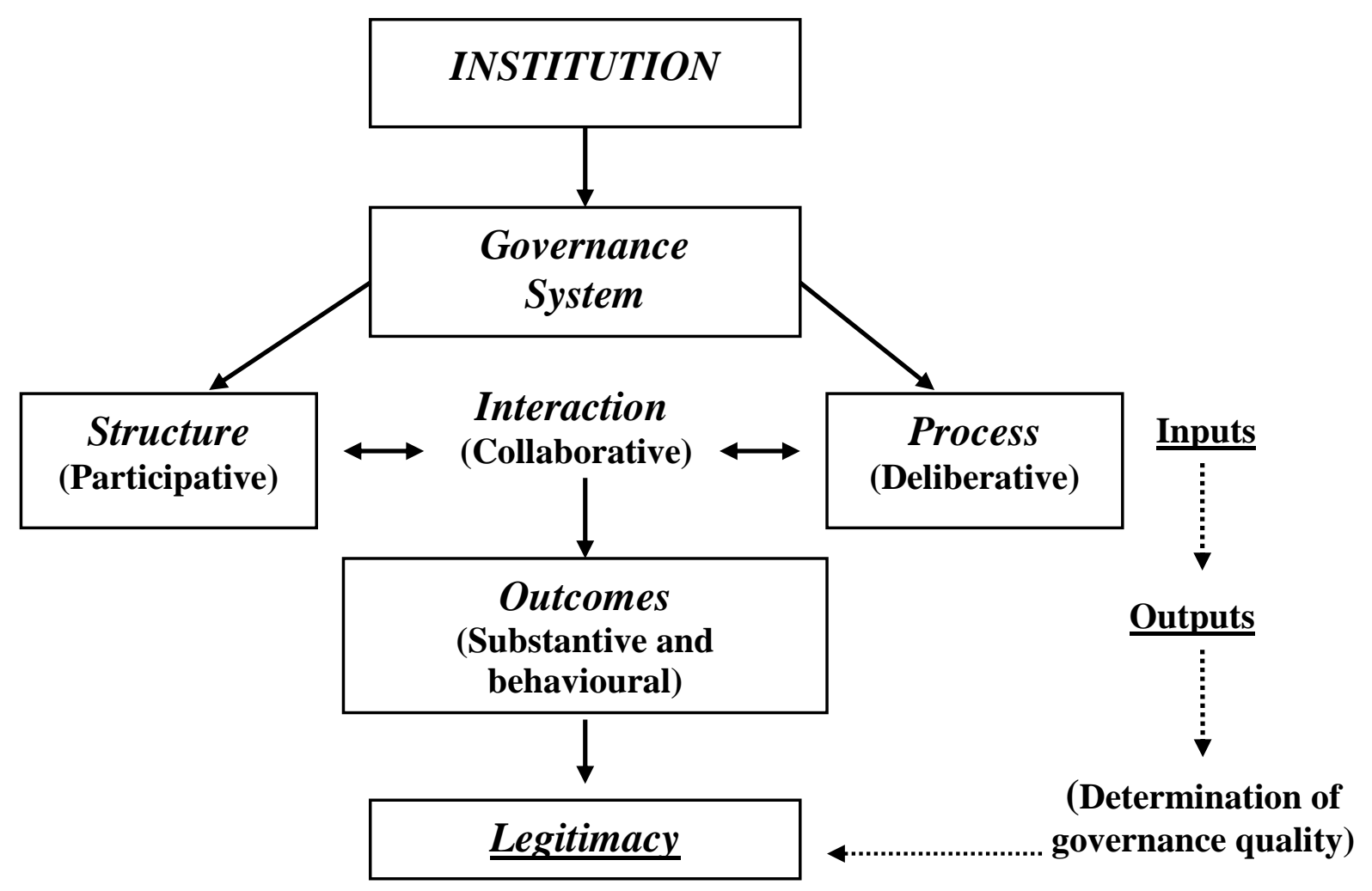

Figure 1. Theoretical model for the evaluation of contemporary global governance (Author 12011 ).

By identifying legitimacy as the end-point of social-political interaction, Author 1 (2011) is able to assemble the identified elements of 'good governance' in the literature into hierarchically consistent framework of principles, criteria and indicators (PC\& $\left.\mathrm{I}^{\dagger}\right)$. Since UNCED, PC\&I have become a primary means for various UN agencies and commissions to evaluate the effectiveness of sustainable development (UN 1993). The total quality of a governance system relates to the interaction between structure, process and outcomes, which together constitute the basis for a set of related principles. Table 1 (below) helps to illustrate the nature of the relationship between the various governance arrangements, synthesising the existing normative concepts of 'good' governance, derived from political science literature, into a hierarchically consistent framework of PC\&I. It is important that attributes are placed at the appropriate level within the framework, do not overlap or duplicate those at another level, and are linked back to the appropriate attribute at a higher level. Correct location of the PC\&I allows for a top-down analysis of principles via criteria and subsequently by indicators, and thus provides the means for reporting on the actual performance of the case studies below.

\section{Notes}

${ }^{\dagger}$ A principle is a fundamental rule or value. Criteria are states or aspects requiring adherence to a principle. Indicators are qualitative or quantitative parameters that are assessed in relation to a criterion, and contribute to the overall determination of performance (Van Bueren and Blom 1997). 
Table 1. Hierarchically consistent framework for the assessment of governance quality

\begin{tabular}{|c|c|c|}
\hline Principle & Criterion & Indicator \\
\hline \multirow[t]{5}{*}{ Meaningful participation } & \multirow[t]{3}{*}{ Interest representation } & Inclusiveness \\
\hline & & Equality \\
\hline & & Resources \\
\hline & \multirow[t]{2}{*}{ Organisational responsibility } & Accountability \\
\hline & & Transparency \\
\hline \multirow[t]{6}{*}{ Productive deliberation } & \multirow[t]{3}{*}{ Decision-making } & Democracy \\
\hline & & Agreement \\
\hline & & Dispute settlement \\
\hline & \multirow[t]{3}{*}{ Implementation } & Behavioural change \\
\hline & & Problem solving \\
\hline & & Durability \\
\hline
\end{tabular}

Source (Cadman 2011)

In this context, a principle is defined as a fundamental rule that serves as a basis for reasoning, the objective of which reasoning is to ascertain the function of the total system in respect to explicit elements of governance. A principle can also express a certain perspective regarding a specific aspect of the system as it interacts, in this context, with the overall governance system (Lammerts van Beuren and Blom 1997). Two underlying structural and procedural concepts of governance discussed above have been elaborated by Cadman (2011: 4) - 'participation as structure' and 'deliberation as process' - both of which contribute to the substantive outcomes, or products, of the system. Consequently, the analysis that follows looks at governance arrangements in terms of their relationship to either structure or process, adopting the perspective that participation, as the fundamental structural aspect of governance, should be meaningful. The term 'meaningful', often associated with participation in the literature, serves here as a normative, qualitative descriptor (Gaventa 2002). The term productive has been used as the descriptor for the principle of deliberation as process (Dryzek and Braithwaite 2000). In this context, the principle refers both to the quality of deliberations as they occur within the system, and to the quality of the outcomes, or products, of those deliberations. Criteria function at the level below principles, and demonstrate compliance with principles in relation to specific aspects or states of the system. They facilitate the assessment of principles that would otherwise be ideational and non-measurable. A criterion can be described as 'a category of conditions or processes' against which a system can be assessed (Montreal Process 1999). Usually, criteria cannot be measured directly, but are formulated to provide a determination on the degree of compliance. Criteria are linked to indicators, which are hierarchically lower, represent quantitative or qualitative parameters, and describe conditions indicative of the state of the governance system as they relate to the relevant criterion (Lammerts van Bueren and Blom 1997). Hence, any discussion of the criteria associated with the principles of meaningful participation and productive deliberation occurs simultaneously with their associated indicators.

In this study, meaningful participation is demonstrated through two criteria: interest representation and organisational responsibility. Interest representation has been linked to three elements of governance that function on the indicator level: inclusiveness, demonstrating who participates in a governance system; equality, indicating the nature of the 
relationship between participants; and resources, referring to the economic, technical or institutional capacity of a participant to represent their interests within the system. Organisational responsibility comprises two indicators: accountability and transparency. These indicators, usually treated together in the literature, refer to the extent to which the behaviour of participating organisations can be called to account both inside the institution and externally by the public at large, as well as being visible, or open to scrutiny by other actors within the institution and beyond. Productive deliberation is demonstrated through two criteria: decision making and implementation. Three indicators are linked to decision making: democracy, referring not to a specific mode of democracy, but rather to the extent to which a system can be deemed to be functioning democratically; agreement, referring to the method in which decisions are reached (e.g. voting or consensus); and dispute settlement, indicating the system's capacity to manage conflict when there is no agreement, or there are challenges to decisions made. Another three indicators are linked to implementation: behaviour change, used to determine whether the implementation of agreements, or substantive outcomes results in changed behaviour regarding the problem that the system was created to address; problem solving, referring to the extent to which the system has solved the problem it was created to address (broadly understood in this paper as atmospheric pollution from excessive greenhouse gas emissions, forest degradation and unsustainable forest management); and durability, capturing the two related elements of adaptability and flexibility, as well as longevity.

\section{Interest representation and decision-making in global governance}

Before looking more closely at the perspectives of some of the state and non-state actors involved in REDD+, this section investigates the views of a range of commentators across the political science disciplines regarding the specific governance arrangements of interest representation and decision-making, in accord with the themes of this special issue of Innovation.

At a structural level, the inclusion, or inclusiveness, of stakeholders is seen as a crucial dimension underlying institutional variation at a global level and is generally associated with interest representation, which is itself as a fundamental problem in contemporary global governance (Koenig-Archibugi 2006; Stiglitz 2006). In examining global democratic practices, theorists have identified relationships between inclusion and equality, and exclusion and inequality. Legitimacy is normatively expressed by equally including all those affected by any given decision within the decision-making process. Part of the current process of governance transformation is the recognition that inclusion bounded by the nation state is an inherently exclusive political form, and the contemporary world 'normatively requires a more open system of global regulation and local and regional interaction' (Young 2000: 13). Systems of representation are most inclusive when they encourage a wide range of previously marginalised groups and perspectives (Young 2000: 13). This has led to a recognition that the complexities of governance brought about by globalisation call for a reinvention of interest representation in post-modern public administration (Rhodes 1997). The collective nature of governance brought about by globalisation raises issues regarding the relationship between interest representation, inclusion and equality (Warren 2002). In such non-spatial and nonterritorial venues 'inequalities are suspect when the voices of those affected are absent' (Warren 2002: 698). A further requirement for effective interest representation is that all participants receive equal capacities and opportunities to participate, using methods that work for all (Warren 2002). Scholars point to the need for economic-technical capacity (money and expertise) as a structural framework condition for developing environmental policy that is 
capable of identifying and resolving ecological problems (Mason 1999). Such resources strengthen participation, and contribute to stakeholder community development, including skills and training (Simmons and Birchall 2005: 275). Capacity building is frequently equated with resources, and refers to "the sum of efforts needed to develop, enhance and utilize the skills of people and institutions to follow a path of sustainable development" (United Nations Development Programme, 2001 cited in Downs 2003: 186). Clearly, without the necessary wherewithal to participate in sustainable development initiatives, stakeholders are unable to represent their interests effectively.

Governance scholars also pay some attention to the need to improve global governance at a procedural level, leading to an observation that 'the processes we use to negotiate global agreements are as important as the ... capabilities ... that the negotiators bring to the negotiating table' (Susskind 2004: 7). Current intergovernmental processes are seen as lacking the necessary vision to cope with greater degrees of non-state participation. This has led to the conclusion that global environmental negotiations will continue to produce inadequate results, unless existing institutional arrangements are changed in favour of more productive interaction, built around consensus rather than majority rule (Susskind 2004). As governance continues to develop at a global level, procedural arrangements are likely to be based more on commonly agreed rules and practices (Keohane 2003). Decision-making is occurring in forums that are more deliberative in procedural style (Held 2003). A number of scholars describe this approach as consisting of discursive procedures for the solving of problems cooperatively (Dryzek 1990; Lafferty and Meadowcroft 1996). Environmentally focused scholars have argued that 'a tradition of consensus building strengthens both openness and the integration of politics and thereby reinforces the institutional conditions for relative success' (Jänicke 1992: 48). The more consensual, it is assumed, the more likely the prospect of implementation, and the more legitimate the decision (Wettestad 2001). Agreement is often reached by consensus during the working stages of negotiation, reverting to a majority vote at the end (Wettestad 2001; Crowfoot and Wondolleck 1990). When conflict occurs within negotiations, or as a result of complaints over procedure, several sources identify the need for dispute-resolution mechanisms (Van Vliet 2006). The inability to resolve conflicts has been identified as a key indicator of governance failure (Stoker 2000). However, decision-making and policy-making, implementation and enforcement inevitably involve conflict amongst interested parties. Provisions for mediation, facilitation, dispute resolution and arbitration are essential should conflicts arise. Interestingly, the arena of environmental governance makes some of the most extensive use of these processes. Procedures of dispute resolution enhance the democracy, quality and fairness of decisionmaking, and increase legitimacy (Bingham et al. 2005).

\section{Case study: method, results, analysis}

\section{1. $R E D D+$}

At the $11^{\text {th }}$ Conference of Parties (COP) in Montreal in December 2005, the UNFCCC first introduced into negotiations an agenda item on reducing emissions from deforestation in developing countries (UNFCCC 2012). At the Bali climate negotiations in 2007, the initial concept was expanded, acknowledging that 'forest degradation also leads to emissions, and needs to be addressed when reducing emissions from deforestation' (UNFCCC 2008). The subsequent '+' was formally added as a consequence of discussions at COP-15 (December 7$18,2009)$, with the aim of placing greater at protecting and enhancing the carbon values of forests, as well as reducing emissions (Parker et al. 2009). REDD+ is best understood as an 
attempt to use the market to reduce greenhouse gas (GHG) emissions associated with forest clearing, by allowing 'avoided deforestation' to be included in carbon trading mechanisms. It is effectively a payment in exchange for actively preserving existing forests (Carbon Positive 2010). Negotiations via the UNFCCC COPs are ongoing and the mechanism is not yet finalised, although a number of demonstration projects and national-level 'readiness' activities are underway (Cerbu et al. 2011). REDD+ is linked to the Kyoto Protocol and its related CDM, offering developed countries a way to meet their emissions targets by reducing GHG emissions and increasing GHG sinks (i.e. forests) in developing countries (CIFOR n.d.).

Effective implementation of REDD+ could contribute to a 50 per cent reduction in global deforestation by 2020 and zero percent by 2030 (Angelsen et al. 2010). By 2030, forest-related mitigation could contribute to more than a third of all reductions in $\mathrm{CO}_{2}$ emissions. Should this occur, it will be essential to have strong national arrangements for verification and certification, including the checking of the accuracy of the data reported (IUCN 2010).

Developed countries provided USD $\$ 4$ billion to REDD+ for the funding period 2010 2012 (Forest Carbon Portal 2010). In May 2010, Norway pledged USD\$1 billion to assist Indonesia to reduce its GHG emissions from deforestation and forest degradation. Representatives of Indigenous peoples and local communities will take part in the planning, implementation and institutional management of the funds allocated for REDD+ in Indonesia (Royal Norwegian Embassy in Jakarata 2010). However, given the lack of clarity over land tenure, and the lack of explicit recognition of Indigenous peoples' rights in the agreement, doubts have been raised over the credibility of these claims (Lang 2010). Such issues as Indigenous peoples' rights - and ensuring the rights of interested and affected parties generally - confront REDD+ with a number of governance challenges. As an example of multilevel, multiactor governance, from the intergovernmental to the local and including a wide range of interests, it has been argued that REDD+ is to address local concerns and global problems, it requires an institutional architecture that is both participatory and deliberative. Where there is a wide range of actors functioning within cross-sectoral partnerships (of which there are now many at the national REDD+ project level), addressing issues of inclusiveness, equality and capacity building, as well accountability and transparency are critical to effective collaboration. Decision-making also requires new political processes for reaching agreement. These should embrace both formal and informal negotiating procedures, and address disputes equitably, should they arise (Forsyth 2009: 113-122). The analysis below explores stakeholder perceptions regarding the extent to which REDD+ is seen to be addressing these governance challenges, focusing on the participatory and deliberative aspects of interest representation and decision-making.

Total $\mathrm{CO}_{2}$ emissions from the Land Use Land Use Change and Forestry (LULUCF) sector in Nepal in the 2000/2001 base year (Second National Communication) was 16,909 gigagrams, which includes 12,561 from forest and grassland conversion and 4,348 from soil (Ministry of Environment, Science and Technology, 2012, Table ES-2a). There is therefore scope to reduce emissions from forests under the REDD+ mechanism in Nepal. Seeing the possibilities of REDD+, Nepal has been implementing different REDD+ initiatives such as the World Bank/FCPF supported REDD+ readiness activities. The REDD+ forestry and Climate Change Cell, a new institutional body, is developed under the Ministry of Forest and Soil Conservation to coordinate and implement REDD+ activities in Nepal. The REDD+ Cell 
has prepared REDD+ readiness proposal, which is aligned with the National Development Strategy.

Pilot activities covering different aspects are underway, providing good lessons for Nepal's REDD+ readiness. About 105 community forests user groups (CFUGs) have been involved in REDD+ pilot projects over the past three years, funded by the Norwegian government's aid agency NORAD and jointly implemented by three renowned NGOs (International Centre for Integrated Mountain Development, ICIMOD; ANSAB; and the Federation of community Forestry Users, Nepal, (FECOFUN). Over the past two years approximately US\$195,000 (US\$ 95,000 in 2011 and US\$100,000 in 2012) has been distributed to 105 REDD+ pilot CFUGs. Approximately $60 \%$ of the fund was distributed for social safeguards (20\% for the poor, $20 \%$ for Dalit/untouchable, $15 \%$ for women and $10 \%$ for Indigenous people) and another $40 \%$ for environmental safeguards (24\% carbon stock maintenance and $16 \%$ for carbon increment). Nepal has a successful history of over three decades of participatory forest resource management. Over 1.6 million ha of national forest is handed over to 17685 community forest user groups (CFUGs), and currently about one third of the total national populations are member of CFUGs (Department of Forests, 2012). The Nepalese REDD+ strategy is aligned with the country's National Development Strategy, and multi-stakeholders and institutional mechanisms are well established and institutionalized as a result of this arrangement.

\subsection{Method}

The researchers have a well-established connection with the different levels of forests stakeholders, facilitating communication with all levels of stakeholders, thereby assisting the organization of a survey of them. The researchers have conducted a large number of time series global surveys on REDD+ (before and after COP 15, COP 16 and COP 17), and have analyzed the perceptions of different sectors, publishing their results in a number of peer reviewed international journals (Cadman and Maraseni 2011 and 2012 and Cadman, Maraseni and Blazey 2012). The survey results therefore constitute the first analysis of REDD+ at the national level undertaken by the researchers, and using the same methodology of previous global-level research. The perceptions of Nepalese stakeholders are important as they are active within a highly decentralized and fully functional community based forest policy environment, and there is a well-established mechanism for involving key forest stakeholders, from the central, to the regional, district and local levels.

Perceptions of the governance of REDD+ were evaluated using the eleven indicators of Table 1 above. Respondents were asked to rate their perceptions anonymously, using a Likert scale: 'very low' (0-1); 'low' (1.1-2); 'medium' (2.1-3); 'high' (3.1-4); and 'very high' (4.1-5). A Likert scale is widely used in assessing the perception of respondents through structured questionnaire surveys, in which respondents specify their level of perception on a given statement (in this case for an indicator). The average of all respondents in a given category captures the collective perception for the indicator within that sub-set of survey respondents (Burns and Burns 2008). This method of assessment is considered a balanced approach to analysis of perceptions because there are equal amounts of positive and negative attributions on the scale. Ordered response choices from seven to nine are occasionally used, although five ordered response levels, as selected for this study, are common (Dawes 2008). These often reflect choice-text using such terms ranging on a scale from 'strongly agree' to 'strongly disagree', i.e. from the positive to the negative. The approach adopted here survey is 
not typical, as the choice-language is designed to address perceptions of governance quality (from very high to very low) rather than agreement/disagreement. 'Low' and 'very low' are not strictly negative positions, but in the context of governance quality these can be interpreted as negative positions. But the overall average value of 'medium' (three) shows a neutral perception on the indicators.

The views of stakeholders were collected via the online survey tool SurveyMonkey (www.surveymonkey.com). All concerned key stakeholders were contacted by email, telephone, Skype, social media and through face-to-face meetings. The survey was deployed between 23 July and 23 August 2011. In order to gain the maximum number of survey participants, the survey was conducted anonymously. The questionnaire asked participants to provide a rating for their perceptions regarding the governance quality of REDD+, using the indicators developed by Cadman (2011) for the evaluation of institutional governance quality. The questions followed previous international-level research, but were translated into Nepalese, and are reproduced in an English summary format in Table 2 below.

Table 2 Summary of survey questions

\begin{tabular}{|l|l|}
\hline Indicator & Question \\
\hline Inclusiveness & Do you think REDD+ is inclusive of your interests? \\
\hline Equality & Do you think REDD+ treats all interests equally? \\
\hline Resources & What level of resources does REDD+ provide for you to participate? \\
\hline Accountability & $\begin{array}{l}\text { Do you think the various institutional elements in which you participate are } \\
\text { accountable in their dealings with you regarding the REDD+ process? }\end{array}$ \\
\hline Transparency & $\begin{array}{l}\text { Do you think the various institutional elements in which you participate are } \\
\text { transparent in their dealings with you regarding the REDD+ process? }\end{array}$ \\
\hline Democracy & $\begin{array}{l}\text { Do you consider the REDD+ processes in which you participate to act in a } \\
\text { democratic manner? }\end{array}$ \\
\hline Agreement & Do you consider the making of agreements in REDD+ to be effective? \\
\hline Dispute settlement & Do you consider the settling of disputes in REDD+ to be effective? \\
\hline Behavioural change & $\begin{array}{l}\text { Do you think REDD+ will contribute to changing the behaviour that leads to } \\
\text { deforestation and forest degradation in developing countries? }\end{array}$ \\
\hline Problem solving & $\begin{array}{l}\text { Do you think REDD+ will help solve the problem of deforestation and forest } \\
\text { degradation in developing countries? }\end{array}$ \\
\hline Durability & Do you consider REDD+ will be durable? \\
\hline Source: Cadman and & arasen 2012 \\
\hline
\end{tabular}

Source: Cadman and Maraseni 2012

The intention of the survey was to target at least 500 individuals, with the anticipation of a response rate of at least $10 \%$. Approximately 350 individuals were contacted directly; others were contacted indirectly through participants recruited into the survey. It was not possible to determine how many further individuals were recruited into the survey in this manner. Of the initial 131 respondents who commenced the survey, 66 individuals fully completed the survey, giving a response rate of approximately $19 \%$ (or $13.2 \%$ had the original target of 500 individuals been achieved). Only the complete survey was considered for the analysis. There are a number of reasons why the survey completion rate was lower than the attempt rate. Online surveys have generally lower participation rates than other forms of survey technique (Van Selm \& Jankowski 2006: 447). In Nepal, the Internet and power system is highly unreliable. During the survey period, there were power cuts averaging 
fourteen hours a day. The survey could take over an hour if stakeholders felt the need to provide extensive comments, and all questions related to the indicators were compulsory. It was also not possible to perform statistical tests as to whether there was any statistically significant difference between the means (averages) of the responding sectors, as the sample size of each subset is lower than 30 in all cases. The sectors were identified after extensive consultation with a wide range of interests, and represent the groups most directly involved in REDD+ in Nepal. Consistent with other surveys conducted by the researchers, a further grouping 'other' was also included. This constituted academics, freelance consultants, media, multilateral and intergovernmental organisations, one hydropower representative, one Indigenous person and one Dalit (low caste). The breakdown of respondent sectors is reproduced in Table 3 below.

Table 3: Nepal REDD+ governance survey: breakdown of attempted and completed surveys by sector

\begin{tabular}{|c|c|c|c|c|c|}
\hline \multirow[b]{2}{*}{ Sector } & \multicolumn{2}{|c|}{ Attempted survey } & \multicolumn{2}{|c|}{ Completed survey } & \multirow[b]{2}{*}{$\begin{array}{c}\% \text { of complete } \\
\text { survey in relation } \\
\text { to attempt }\end{array}$} \\
\hline & $\begin{array}{c}\text { No of } \\
\text { attempts }\end{array}$ & $\begin{array}{l}\% \text { of total } \\
\text { attempts }\end{array}$ & $\begin{array}{c}\text { No of complete } \\
\text { survey }\end{array}$ & $\begin{array}{c}\% \text { of } \\
\text { complete } \\
\text { survey }\end{array}$ & \\
\hline Aid program & 7 & 5.3 & 3 & 4.5 & 42.9 \\
\hline Forest user group & 11 & 8.4 & 7 & 10.6 & 63.6 \\
\hline Dalit organisation & 2 & 1.5 & 2 & 3 & 100 \\
\hline Finance & 3 & 2.3 & 1 & 1.5 & 33.3 \\
\hline Forest-based industry & 3 & 2.3 & 3 & 4.5 & 100 \\
\hline Government & 23 & 17.6 & 11 & 16.7 & 47.8 \\
\hline $\begin{array}{l}\text { Indigenous } \\
\text { organisation }\end{array}$ & 3 & 2.3 & 1 & 1.5 & 33.3 \\
\hline Madhesi group & 3 & 2.3 & 1 & 1.5 & 33.3 \\
\hline NGO & 49 & 37.4 & 21 & 31.8 & 42.9 \\
\hline $\begin{array}{l}\text { Women's } \\
\text { organisation }\end{array}$ & 1 & 0.8 & 0 & 0 & 0 \\
\hline Others & 26 & 19.8 & 16 & 24.2 & 61.5 \\
\hline Total & 131 & & 66 & & 50.4 \\
\hline
\end{tabular}

The number of attempts was 131. The highest number of attempts was from the NGO sector, followed by Other, Government and Forest user groups, whereas lowest attempt was from women's organisations and Dalit (low caste) organisations. In total, 66 people or about $50 \%$ of the attempted people/sector completed the survey. As with the survey attempts, the highest number of completed surveys were from NGO sector, followed by government. In terms of the ratio of completed surveys to attempted surveys, Dalit organisations and forest based industry were top the list, with $100 \%$ completion rate, but the response rates are too low to be significant. The NGO and Government sectors, which had highest number of attempted and competed surveys, achieved $42.9 \%$ and $47.8 \%$ respectively. Women's organisations achieved a zero completion rate. The researchers were informed by a number of women who completed the survey that they had chosen to categorize themselves by other sectors, on the basis of their employment. Other sectors, notably Dalit, Indigenous organisations and forest industry informed the researchers that individuals discussed the questions together and opted 
to attempt the survey as a group. Therefore, although the number of responses from these groups seems small, they represent a common voice of their representative organisation. While this cannot be taken into consideration statistically, such small sample sizes do not automatically mean that minority voices were not represented.

A number of further observations need to be made at this point regarding the results presented below. Respondents rated REDD+ at the indicator level. A question has arisen in similar studies of global governance as to whether qualitative data - the method used here can be applied to develop quantitative results. The conversion of verbal descriptions (low, medium, high) into numerical results can lead to judgments hidden underneath the apparent authority of a number, and the pretension of exact science (Nanz and Steffek 2005: 373). There has also been an aggregation of scores at the indicator level to produce results at both the criterion and principle levels, and the overall score. In some instances, this has resulted in a situation where REDD+ performed poorly in one indicator but met the threshold at the criterion level, or did not meet the criterion-level threshold, while still meeting requirements at a principle level. These factors should be taken into account when looking at the 'pass/fail' results for each survey. It must also be stated that the numbers of respondents are low. This may have resulted in an 'outlier' effect, where very low numbers of respondents in one group can overly influence the results. It is therefore not possible to make definitive claims, but the results presented below are useful for exploratory analysis. Consequently, taking all these factors into consideration, this study should therefore be seen as a work in progress requiring further research to determine whether the trends identified are correct across the 'universe' of stakeholders involved in REDD+ at the national level in Nepal.

\subsection{Results}

The results from the surveys were analysed using Statistical Package for the Social Sciences (SPSS). The ratings at the indicator scale were aggregated under the relevant criterion; in turn the relevant criteria were combined to provide a result at the principle level. These principle-level results were added to provide an overall 'legitimacy score', out of fiftyfive. A conventional pass/fail target value of $50 \%$ has been applied to the overall score. ${ }^{\ddagger}$ The comprehensive results across all eleven indicators and associated criteria and principles are produced in Table 4, below.

\footnotetext{
$\$$ 'A reference value to strive for is called a target value' (Lammerts van Beuren and Blom 1997: 24, bold in original).
} 
Table 4: Perception of Nepalese key stakeholders on REDD+ governance quality

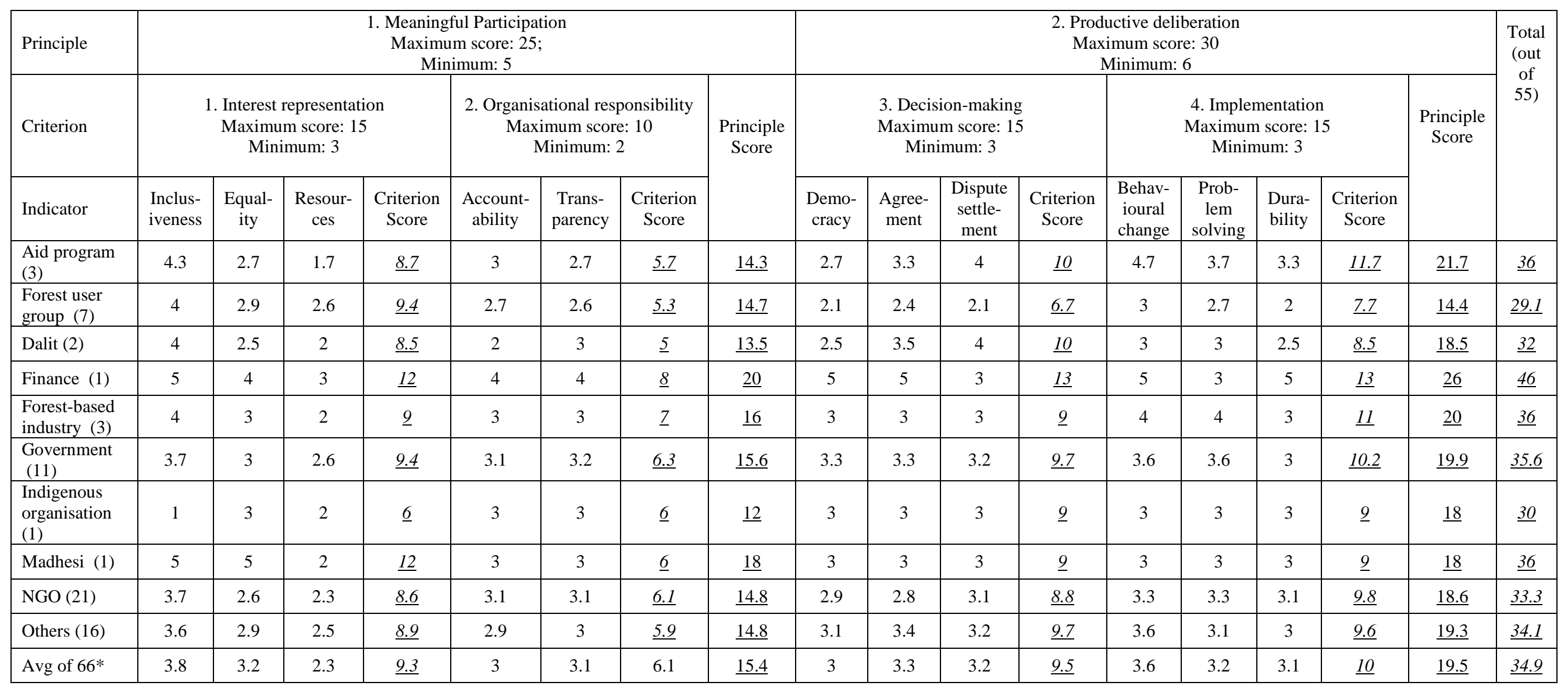

Source: online survey in July 2011 


\subsection{Analysis}

Overall, the results appear to demonstrate that stakeholder perspectives regarding the governance quality and legitimacy of REDD+ in Nepal have been relatively positive to date, with an average overall score of 34.9 out of 55. There were both similarities and differences in respondents' perceptions of REDD+. In terms of the final scores, Forest Users were the most negative, with an overall score of 29.1, closely followed by Indigenous (30), and Dalit (32). Regarding forest users, this is of some concern, as they are clearly one of the most important stakeholder groups. However, this is mitigated by the fact that this score was still a 'pass' for the mechanism (27.5 is the pass score). The highest scores were for Finance (46), and a cluster around Aid, Forest Industry and Madhesi (36 each). The remaining sectors, namely NGOs, Others and Government scored REDD+ somewhere in the middle, and were relatively close to each other: NGOs were the lowest (33.3), followed by Others (34.1), and Government (35.6). However, the results of sectors with low response rates should be treated cautiously, in view of the outlier effect referred to earlier.

The trends in overall scores generally followed a similar pattern amongst respondent sectors at the indicator level. However, it is worth noting that there was an obvious 'low' cluster for the resources indicator amongst all sectors, with the average rating in Table 4 being only 2.3 ('medium'), 1.7 for Aid ('low') and 2 for Forest Industry, Dalit and Madhesi (also 'low'). Previous research suggests this is a feature in other areas of global environmental governance, and forestry in particular. A lack of financial, technical and institutional support (money, know-how and infrastructure) can have a knock on effect for interest representation, impacting on the efficacy of both inclusiveness and equality (Cadman 2011: 12-13; 181-182). However, by way of mitigation, it should be noted that inclusiveness was the highest scoring indicator overall (3.8). Equality also performed on a par with problem-solving and dispute settlement (3.2). It is encouraging to note that respondents awarded behaviour change relatively well by sector, resulting in the second highest overall rating (3.6). This may reflect positively on REDD+ in Nepal: respondents in this survey appeared to think that REDD+ would help change behaviour that led to deforestation and forest degradation. The next highest indicator was agreement (3.3): again, the response across sectors was relatively positive; this may demonstrate that stakeholders are content with the methods used to reach agreement within processes for REDD+ decision-making. Transparency and durability performed less well (3.1), and the same can be said for and accountability and democracy (3); but all are still well over the 'pass' threshold of 2.5.

Nevertheless, there are some poorly-performing indicators amongst specific sectors. The Indigenous respondent rated inclusiveness 'low' (but there may be an outlier effect here). Ratings of 'low' were also given to accountability by Dalit, and to durability by Forest Users; this rating by Forest Users is again of concern - if this sector does not have confidence that REDD+ will last, there may be a lack of interest in implementation. Dispute settlement and democracy also only achieved a rating of 2.1 each with this sector - possibly further signs that Forest Users are not entirely happy with REDD+ decision-making.

On the basis of the responses to this survey it is fair to say that (with the exception of the one identified Indigenous representative), REDD+ in Nepal was perceived to be inclusive. Interest representation is function relatively well functioning well in the country, but the 'low' rating for resources should be of concern to all stakeholders. In so far as this reflects a trend across the research undertaken by the authors, REDD+ policy-makers at the national and international levels should be concerned. Decision-making appears to be functioning well in REDD+ in Nepal, challenging the trend identified by the authors amongst stakeholders in REDD+ at the international level, who were 
far more negative about the mechanism's ability to settle disputes. However, there is no room for complacency at the national level, with the survey possibly revealing that those forest users who responded to the survey had unresolved disputes regarding the mechanism, and did not consider it particularly democratic.

\section{Conclusions}

This study has presented a nuanced framework of evaluation based on a complex of institutional arrangements (such as interest representation and decision-making) for 'good', governance, which they have equated with quality and legitimacy. REDD+ comprises multi-actors and is an ideal institutional venue in which to examine stakeholder perceptions of global environmental governance. Given the mix of actors in REDD+, the methods of participation and deliberation associated with negotiations are as important as the decisions made about a given issue. In view of the collaborative, and 'partnership'-based model of REDD+ on the ground, there are increased expectations about the role of non-state actors, and this has created some dynamic tensions in the relations between nonstate and state actors in the formulation of REDD+ policy at the international level. Southern state and non-state interests will increasingly benefit from REDD+ projects in developing countries. But previous research by the authors suggests there is something of a 'divide' in perceptions between Northern and Southern stakeholders, i.e. from developed and developing countries (Cadman and Maraseni 2011, 2012). It is interesting to reflect on whether the trends for Southern stakeholder preference for REDD+ over their Northern counterparts may be reflected in the national-level, developing country, survey presented here.

However, while state and non-state actors in Nepal perceive REDD+ to be inclusive, they have concerns about the extent to which it is providing the necessary capacity for stakeholders to participate meaningfully. The relatively weak rating for resources may reflect the reality that few stakeholders have the wherewithal to participate in mechanisms for global environmental governance on the ground. There have been significant positive participatory developments in governance since Rio in 1992, and over the last 20 years, particularly the increased role for non-state actors, such as NGOs. It is interesting to note the similarity of perceptions between NGOs and Government at the national level in Nepal. This may reflect the reality on the ground that these actors represent two key sectors for global policy implementation in developing countries. However, more research across a larger number of participants in REDD+ in Nepal is required to determine if these results are indicative of broader national-level perceptions - even if they appear to reflect trends at the international level. 


\section{References}

Andonova, B., Betsill, M., and Bulkeley, H., 2010. Transnational climate governance. Global environmental politics, 9 (2), 52-73.

Angelsen, A., Brown, S., Loisel, C., Peskett, L., Streck, C., Zarin, D., 2009. Reducing emissions from deforestation and forest degradation (REDD): an options assessment report. Washington, DC: Meridian Institute.

Anonymous. 2007. The NLBI: where's the meat? Earth negotiations bulletin 13 (162), 18.

Barnett, J., 2010. Adapting to climate change: three key challenges for research and policy - an editorial essay. Wiley Interdisciplinary Reviews: Climate Change 1 (3), 314-317.

Biermann, F., Betsill, M., Gupta, J., Kanie, N., Lebel, L., Liverman, D., Schroeder, H., Siebenhuener, B. 2009. Earth system governance: people, places and the planet. Bonn, Germany: Earth System Governance Project.

Biermann, F. and Gupta, A. 2011. Accountability and legitimacy in earth system governance: a research Framework' Ecological economics 70 (11) September 15, 2011. p. 1856-1864

Berger, G. 2003. Reflections on governance: power Relations and policy making in regional sustainable development. Journal of environmental policy and planning, 5 (3), 219-234.

Bingham, L., O'Leary, R. and Nabatchi, T. (2005). Legal frameworks for the new governance: processes for citizen participation in the work of government. National civic review. Spring: $54-61$.

Birnie, P., 2000. The UN and the environment. In: A. Roberts and B. Kingsbury, eds. United nations, divided world. Oxford: Oxford University Press, 327-383.

Brechet, T. and Lussis, B. 2006. The contribution of the clean development mechanism to national climate policies. Journal of policy modelling, 28 (9), 981-994.

Bulkeley, H., 2010. Climate policy and governance: an editorial essay. Wiley interdisciplinary reviews: climate change, 1 (3), 311-313.

Bumpus, A. and Cole, J., 2010. How can the current CDM deliver sustainable development? Wiley interdisciplinary reviews: climate change, 1 (4), 541-517.

Burns, A. and Burns, R. 2008. Basic marketing research. Second edition. New Jersey: Pearson Education.

Cadman, T. 2011. Quality and legitimacy of global governance : case lessons from forestry. Houndmills, Basingstoke, Hampshire; New York, Palgrave Macmillan.

Cadman, T. and Maraseni, T. 2011. The governance of climate change: evaluating the governance quality and legitimacy of the United Nations' REDD-plus programme. International journal of climate change: impacts and responses, 2 (3), 103-123

Cadman, T. and Maraseni, T. 2012. The Governance of REDD+: An Institutional Analysis in the Asia Pacific Region and Beyond. Journal of environmental planning and management, 55 (4), 617-635

Cadman, T., Maraseni, T. and Blazey, P. 2012. Perspectives on the quality of global environmental governance: an evaluation of NGO participation in global climate negotiations in the Asia Pacific and beyond. Third Sector Review, in press.

Cashore, B, Auld, G. and Newsom, D., 2004. Governing Through Markets: Forest Certification and the Emergence of Non-State Authority. New Haven and London: Yale University Press.

Carbon Positive, 2010. Glossary. http://www.carbonpositive.net/viewarticle.aspx?articleID=44 accessed 010/10/2010.

Cerbu, G., Swallow, B., and Thompson, D., 2011. Locating REDD: a global survey and analysis of REDD readiness and demonstration activities. Environmental science and policy, 14 (2), 168-180. 
Centre for International Tropical Forestry (CIFOR). Undated. Simply REDD: CIFOR's guide to forests, climate change and REDD. Bogor: CIFOR. http://www.cifor.cgiar.org/publications/pdf_files/.../MediaGuide_REDD.pdf, accessed 01/10/2010.

Crowfoot, J. and Wondolleck, J. 1990. Environmental disputes: community involvement in conflict resolution. Washington and Clovello: Island Press.

Dawes, J. 2008. Do Data characteristics change according to the number of scale points used? An experiment using 5-point, 7-point and 10-point scales. International journal of market research 50 (1), 61-77.

Department of Forests. 2012. Community forestry user group database record, Community Forest Division. Department of Forests (DoF), Kathmandu, Nepal.

Dryzek, D. 1990. The politics of the earth: environmental discourses. New York: Oxford University Press.

Dryzek, J. and Braithwaite, V., 2000. On the Prospects for Democratic Deliberation: Values Analysis Applied to Australian Politics Political Psychology 21 (2), 241-266.

Down, T. 2002. A participatory integrated capacity building approach to the theory and practice of sustainability - Mexico and New England watershed case studies. In: W. Filho

(ed.) International Experiences on Sustainability. Frankfurt am Main: Peter Lang, 179205.

Farrell, K. 2003. Recapturing fugitive power: epistemology, complexity and democracy. Local environment 9 (5) (2003), 469-470.

Forest Carbon Portal. 2010. Multilateral interim REDD+ partnership established in Oslo. http://www.forestcarbonportal.com/resource/interim-redd-partnership-established-oslo, accessed 02/10/2010.

Forsyth, T. 2009. Multilevel, multiactor governance in REDD+: participation, integration and coordination. In: A. Angelsen (ed.), Realising REDD+: national strategy and policy options. Bogor: CIFOR, 113-122.

Gaventa, J, 2002. Making Rights Real: Exploring Citizenship, Participation and Accountability, Journal of International Development Studies 33 (2), 1-11

Gilenwater, M. 2012. What is additionality? Part 1: a long-standing problem. No location: GHG Management. ghginstitute.org/wp.../AdditionalityPaper_Part-1(ver3)FINAL.pdf, accessed 06/04/2012.

Glück, P., Rayner, J., Cashore, B., Agrawal, A., Bernstein, S., Capistrano, D., Hogl, K., L. Bernd-Markus, McDermott C., Maini, J. Oksanen, T., Ollonqvist, P., Pülzl, H., Rametsteiner E. and Pleschberger, W. 2005. Changes in the governance of forest resources. In: Mery, G., Alfaro, R., Kaninnen, M. and Lobovikov M. eds. Forests in the Global Balance. Helsinki: International Union of Forest Research Organisations (IUFRO), 51-74.

Gulbrandsen, Lars H., 2005. Explaining Different Approaches to Voluntary Standards: A study of Forest Certification Choices in Norway and Sweden, Journal of Environmental Policy and Planning 7 (1),43-59.

Held, D. 2003. Executive to cosmopolitan multilateralism. In: Held, D. and KoenigArchibugi, M. eds. Taming globalization: frontiers of governance. Cambridge: Polity Press, 160-187.

Humphreys, D. 1996. Forest politics: the evolution of international cooperation. London: Earthscan.

International Union for the Conservation of Nature (IUCN). 2010. REDD+: scope and options for the role of forests in climate change mitigation strategies. http://cmsdata.iucn.org/downloads/redd_scope_english.pdf, accessed 21/05/2010.

Jänicke, M. 1992. Conditions for environmental policy success: an international comparison. The environmentalist 12 (1992), 47-58. 
Juhola, S. and Westerhoff, L., 2011. Challenges of adaptation to climate change across multiple scales: a case study of network governance in two European countries. Environmental science \& policy, 14 (3), 239-247.

Kedia, B., Lahiri, S., and Mukherjee, D., 2006. BRIC economies: earlier growth constraints, contemporary transformations and future potential, and key challenges. In: S. Jain, ed. Emerging economies and the transformation of international business: Brazil, Russia, India, China (BRICS). Cheltenham: Edward Elgar, 46-74.

Keohane, R. 2003. Global governance and democratic accountability. In: Held, D. and KoenigArchibugi, M., eds. Taming globalization: frontiers of governance. Cambridge: Polity Press, $130-159$.

Koenig-Archibugi, M. 2006. Introduction: institutional diversity in global governance. In: KoenigArchibugi, M. and Zürn, M., eds. New modes of governance in the global system: exploring publicness, delegation and inclusiveness. Basingstoke and London: Palgrave Macmillan, 130.

Kooiman, J., 2000. Societal governance: levels, models, and orders of social-political interaction. In: J. Pierre, ed. Debating governance: authority, steering and democracy. Oxford: Oxford University Press, 138-166.

Lafferty, W., Meadowcroft, J. 1996. Democracy and the environment: prospects for greater congruence. In: Lafferty W. and Meadowcroft J., eds. Democracy and the environment: problems and prospects. Cheltenham and Lyme: Edward Elgar, 256-272.

Lammerts van Bueren, E. and Blom, E., 1997. Hierarchical framework for the formulation of sustainable forest management standards. Leiden: The Tropenbos Foundation.

Lang, C. 2010. Norway-Indonesia forest deal: US\$1 billion dollars worth of continued deforestation? REDD Monitor 28/05/2010, http://www.redd-monitor.org/2010/05/28/norway-indonesiaforest-deal-us1-billion-dollars-worth-of-continued-deforestation/, accessed 07/10/2010.

Lovell, H. 2010. Governing the carbon offset market. Wiley interdisciplinary reviews: climate change, 1 (May/June), 353-362.

Mason, M. 1999. Environmental democracy. New York: St Martin's Press.

Ministry of Environment, Science and Technology.2012. National greenhouse gas inventory report for second national communication to the conference of the Parties of the United Nations Framework Convention on Climate Change, Ministry of Environment, Science and Technology, June, 2012, 81p

Montreal Process, 1999. Criteria and indicators for the conservation and sustainable management of temperate and boreal forest ecosystems, second edition. (No location: Montreal Process).

Nanz P. and Steffek, J. 2005. Assessing the democratic quality of deliberation in international governance: criteria and research strategies. Acta politica, 40 (3), 368-383.

Parker, C., Mitchell, A., Trivedi, M., and Mardas, N. 2009. The little REDD+ book. Oxford: Global Canopy Programme.

Paterson, M. and Stripple, J. 2007. Singing climate change into existence: on the territorialization of climate policy making. In: Pettinger, M., ed. The social construction of climate change: power, knowledge, norms, discourses. Aldershot and Burlington: Ashgate, 149-172.

Pierre J. and Peters, B. 2000. Governance, politics and the state. London: Macmillan Press.

Rhodes, R. 1997. Understanding governance: policy networks, governance, reflexivity and accountability. Buckingham: Open University Press.

Royal Norwegian Embassy in Jakarta. 2010. Norway-Indonesia REDD+ partnership - frequently asked questions. http://www.norway.or.id/Norway_in_Indonesia/Environment/-FAQNorway-Indonesia-REDD-Partnership-/, accessed 07/10/2010. 
Simmons, R. and Birchall, J. 2005. A joined-up approach to user participation in public services: strengthening the 'participation chain'. Social policy and administration 39 (3), 260-283.

Smismans, S. 2004. Law, legitimacy, and European governance. Oxford: Oxford University Press.

Sterk, W. and Wittneben. 2006. Enhancing the clean development through sectoral approaches: definitions, applications and ways forward. International environmental agreements, 6 (3), 271-287.

Stiglitz, J. 2006. Globalization and development. In: Koenig-Archibugi, M. and Zürn, M., eds. New modes of governance in the global system: exploring publicness, delegation and inclusiveness. Basingstoke and London: Palgrave Macmillan, 47-67.

Stoker, G., 2000. Urban political science and the challenge of urban governance. In: J. Pierre, ed. Debating governance: authority, steering and democracy. Oxford: Oxford University Press, 91-109.

Susskind, L. 2004. Environmental diplomacy: negotiating more effective global agreements. New York, Oxford: Oxford University Press.

United Nations, 1993. Agenda 21: programme of action for sustainable development, Rio declaration on environment and development, statement of forest principles. New York: United Nations Publications Department of Public Information.

United Nations, 1993b. Procedural arrangements for the commission on sustainable development. http://www.un.org/documents/ecosoc/res/1993/eres 1993-215.htm, accessed 04/06/2012.

United Nations, 2000. Resolutions and Decisions of the Economic and Social Council. ECOSOC Resolution 2000/35. http://www.un.org/esa/forests/pdf/2000_35_E.pdf, accessed 06/04/2012.

United Nations, 1992. Rules of procedure of the economic and social council. www.un.org/en/ecosoc/about/pdf/rules.pdf, accessed 06/04/2012.

United Nations, 1998. Kyoto protocol to the United Nations framework convention on climate change. No location: United Nations. unfccc.int/resource/docs/convkp/kpeng.pdf, accessed 06/04/2012.

United Nations, 2000. Resolution 2000/35, ECOSOC, 'Report of the Fourth Session of the Intergovernmental Forum on Forests,' 18 October 2000, http://www.un.org/documents/ecosoc/dec/2000/edec2000-inf2-add3.pdf, accessed 15/03/03.

United Nations Department of Economic and Social Affairs/Secretariat of the United Nations Forum on Forests (UNDESA). No date. Frequently Asked Questions. http://www.un.org/esa/forests/faq.html, accessed 15/03/07.

United Nations Department of Economic and Social Affairs/Secretariat of the United Nations

Forum on Forests (UNDESA). 2004. United nations forum on forests. Global partnership: for forests for people fact sheet 1. http://www.un.org/esa/forests/factsheet.pdf, accessed 28/10/04.

United Nations Framework Convention on Climate Change (UNFCCC). 2008. Report of the conference of the parties on its thirteenth session, held in Bali from 3 to 15 December 2007. unfccc.int/resource/docs/2007/cop13/eng/06a01.pdf, accessed 06/04/2012.

United Nations Forum on Forests (UNFF). 2003. Report on the third session (15 March 2002 and 26 May to 6 June 2003). http://daccess-dds ny.un.org/doc/UNDOC/GEN/N03/404/39/PDF/N0340439.pdf?OpenElement, accessed 06/04/2012.

United Nations Forum on Forests (UNFF). 2011. Clean development mechanism, the United nations framework convention on climate change. http://cdm.unfccc.int/index.html, accessed 20/04/2011.

United Nations Framework Convention on Climate Change (UNFCCC). 2012. Reducing emissions from deforestation in developing countries. http://unfccc.int/methods_and_science/lulucf/items/4123.php, accessed 06/04/2012. 
Van Selm, M. and Jankowski, W. 2006. Conducting online surveys. Quality \& quantity 40 (3), 435456.

Van Vliet, M. 1993. Environmental regulation of business: options and constraints for communicative governance. In: Kooiman, J., ed. Modern governance: new government society interactions. London: Sage, 105-118.

Warren, M. 2002. What can democratic participation mean today? Political theory 30 (5), 677-701.

Wettestad, J. 2001. designing effective environmental regimes: the conditional keys. Global governance 7 (3), 317-341.

World Bank, 2011. BioCarbon fund experience insights from afforestation and reforestation clean development mechanism projects summary. New York: Carbon Finance Unit.

Young, I. 2000. Inclusion and democracy. Oxford: Oxford University Press. 